\title{
Pengembangan Dan Pendampingan Literasi Digital Untuk Peningkatan Kualitas Remaja Dalam Menggunakan Internet
}

\author{
Yuli Candrasari*1, Dyva Claretta ${ }^{2}$, Sumardjiajti ${ }^{3}$ \\ ${ }^{123}$ Program Studi Ilmu Komunikasi, FISIP, UPN “Veteran” Jawa Timur \\ *e-mail: yuli candrasari.ilkom@upnjatim.ac.id ${ }^{1}{ }_{2}$ \\ dyva claretta.ilkom@upnjatim.ac.id ${ }^{2}$ sumardjiajti.ilkom@upnjatim.ac.id $^{3}$
}

\begin{abstract}
The teenagers in Gunungsari village, Bumiaji sub-district already have a smartphone and use the gadget without any guidance and assistance from their parents, most of whom are farmers and farm workers with a low level of education. The dropout rate is quite high as a result of the increasing unemployment rate and immoral issues have surfaced in the life of Gunungsari people since their children got to know the internet. The purpose of this community service program is to apply the results of digital literacy research and mentoring youth in using digital media in a healthy way and how mothers can assist children in using the internet in a healthy manner. The results obtained from the Digital Literacy training in adolescents who are adolescents of Gunungsari village are able to protect their privacy in cyberspace and teenagers can have good digital literacy. Whereas in the Mother group, digital literacy has been achieved even though at the basic stage, it is around the issue of how to protect children from dependence on the internet and the mothers have downloaded applications that can be used to protect children.
\end{abstract}

Keywords: Digital Literacy, youth, community service, creativepreneur, healthy internet

\section{Abstrak}

Para remaja di desa Gunungsari kecamatan Bumiaji sudah mempunyai smartphone dan menggunakan gadgetnya tersebut tanpa pernah ada bimbingan dan pendampingan dari para orang tua mereka yang sebagian besar adalah petani dan buruh tani dengan tingkat pendidikan yang rendah. Angka putus sekolah cukup tinggi akibatnya angka pengangguran pun meningkat dan permasalahan-permasalahan amoral pun mengemuka dalam kehidupan masyarakat Gunungsari sejak anak-anak mereka mengenal internet. Tujuan dari kegiatan pengabdian masyarakat ini selain untuk mengaplikasikan hasil penelitian tentang literasi digital dan pendampingan remaja dalam menggunakan media digital secara sehat dan bagaimana Ibu-Ibu mampu mendapingi anak dalam menggunakan internet secara sehat. Pelatihan Literasi Digital dilakukan pada kelompok remaja dan ibu-ibu di desa tersebut. Evaluasi keberhasilan pelatihan tersebut dilakukan dengan menggunakan diskusi dan simulasi tentang bagaimana cara Ibu menghadapi anak yang memiliki kecenderungan ketergantungan yang tinggi terhadap internet.

Kata Kunci: Literasi Digital, remaja, pengabdian masyarakat, creativepreneur, internet sehat

\section{PENDAHULUAN}

Desa Gunungsari kecamatan Bumiaji yang terletak di kota Administratif Batu ini merupakan desa yang terkenal dengan pertanian sayur dan peternakan sapi perah. Desa Gunungsari ini sejak tahun 2015 terkenal sebagai desa dengan penghasil bunga mawar potong. Sebagian besar kehidupan penduduknya ditopang dari pertanian bunga mawar tersebut. Dari pertanian bunga mawar itulah warga desa Gunungsari kehidupan ekonomi masyarakat sekitarnya meningkat.

Sebagai desa yang terletak di daerah wisata tingkat penggunaan internet juga sangat tinggi, hal ini dikarenakan akses internet di kota batu juga sudah sangat mudah dan murah. Didukung dengan semakin murahnya smartphone sehingga terjangkau oleh masyarakat kebanyakan. Sebagaimana hasil survei dari APJII (2016) bahwa pengguna internet 86\% mengakses internet dengan menggunakan handphone/smartphone. Bahkan saat ini smartphone dan mengakses internet sudah menjadi bagian dari gaya hidup remaja termasuk remaja yang ada di desa Gunungsari. 
Para remaja di desa Gunungsari kecamatan Bumiaji tersebut sejak usia 9 tahun sudah mengenal internet. Mereka sudah mempunyai smartphone dan menggunakan gadgetnya tersebut sejak kecil. Hal itu diperparah dengan masuknya Warung Internet (Warnet) di dalam lingkungan desa tersebut. Merebaknya warnet di lingkungan desa Gunungsari kecamatan Bumiaji tersebut mengakibatkan menunrunnya motivasi belajar anak-anak karena anak-anak usia sekolah lebih senang mengunjungi warnet setiap hari daripada sekolah. Anak-anak di desa Gunungsari tersebut rela antri masuk warnet meskipun warnet tersebut belum dibuka. . Bahkan ada beberapa anak yang sudah mulai kecanduan terhadap game online. Hal itu terlihat dari perilaku anak yang setiap hari memaksa orang tuanya untuk meminta uang yang akan digunakan untuk membayar sewa di warnet. Hal ini menimbulkan keresahan pada orang tua khususnya para Ibu yang melihat kondisi tersebut. Keadaan tersebut terjadi karena selama ini anak-anak tidak pernah ada bimbingan dan pendampingan dari para orang tua mereka yang sebagian besar adalah petani. Dengan pekerjaan sebagai petani dan buruh tani dengan tingkat pendidikan yang sebagian besar (51\%) hanya setingk at Sekolah dasar (SD) dan 20\% berpendidikan SMP (berdasarkan data profil desa Gunungsari 2014-2016) maka bisa dikatakan tingkat kompetensi terhadap media digital para orang tua di desa Gunung sari tersebut sangat rendah. Mereka hanya mengenal bahwa smartphone atau handphone untuk melakukan telepon dan mengirim SMS atau WA, selebihnya para orang tua tersebut tidak memahami apa saja yang bisa dilakukan melalui smartphone. Sebagaimana hasil penelitian yang menyebutkan bahwa remaja lebih cepat mengadopsi Internet dan memiliki kemampuan yang lebih baik daripada orang tua mereka. Kedua generasi setuju bahwa remaja tahu lebih banyak tentang Internet daripada orang tua mereka (Lenhart et al., 2001)

Hasil penelitian yang dilakukan sebelumnya tentang pendampingan Ibu pada anak dalam menggunakan internet didapatkan bahwa anak-anak sebagai pengguna internet telah mengenal internet sejak mereka usia balita. Bahkan sejak mereka usia 8-9 tahun sudah difasilitasi dengan laptop atau smartphone. Selain itu anak-anak tersebut juga mendapatkan akses internet di rumahnya berupa wifi atau mendapatkan kuota data pada masing-masing gadgetnya (Claretta, Arianto, 2017). Anak-anak mengakses internet selepas sekolah dan rata-rata menghabiskan waktu 2 jam sehari. Selain itu anak-anak biasa mengakses internet tanpa pantauan bahkan pendampingan dari orang tua, karena kesibukan dari para orang tua. Anak-anak tidak mendapatkan bimbingan dan arahan bagaimana menggunakan internet yang baik.

Fakta tersebut menggambarkan bahwa pengguna internet di Indonesia tumbuh menjadi pengguna yang pasif. Artinya mereka hanya menjadi pengguna yang konsumtif terhadap aplikasiaplikasi yang ditawarkan dalam teknologi digital tanpa pendayagunaan teknologi digital dengan optimal. Dapat dikatakan bahwa personal competence pengguna internet di Indonesia masih rendah. Hal ini sejalan dengan hasil penelitian yang dilakukan Kurniawati dan Baroroh (2016) yang dilakukan pada mahasiswa di Bengkulu menyimpulkan bahwa pemahaman mahasiswa tentang media digital pada kategori sedang yang berarti bahwa mahasiswa yang memiliki gadget canggih mayoritas belum sepenuhnya memahami penggunaan gadget secara benar dan optimal. Akibatnya kemampuan dalam mengoperasikan media tidak terlalu baik, kemampuan dalam menganalisa content tidak terlalu baik dan kemampuan berkomunikasi lewat media terbatas. Demikian juga hasil penelitian yang dilakukan Sasmito, Wijayanto dan Zulfikar (2020: 188) menyatakan bahwa semua guru dan siswa telah menggunakan internet secara maksimal, akan tetapi banyak yang belum memahami perkembangan internet saat ini sehingga belum memanfaatkan internet secara maksimal.

Kondisi tersebut mengakibatkan masyarakat pengguna internet rentan terkena dampak negatif berupa rusaknya tatanan-tatanan sosial dan budaya dalam kehidupan masyarakat. Bahwa teknologi akan menimbulkan perubahan budaya sosial pada masyarakat nampaknya sebuah keniscayaan. Hal itu terjadi ketika masyarakat yang mengadopsi teknologi baru tidak memiliki kemampuan, kompetensi dan pengetahuan yang rendah terhadap teknologi tersebut

Kondisi tersebut saat ini yang juga terjadi di desa Gunungsari tersebut. Remaja bisa mengakses apa saja dalam internet termasuk konten porno melalui smartphone mereka tanpa ada 
pengawasan dari orang tua mereka. Selain menggunakan gadget remaja desa Gunungsari tersebut juga banyak yang mengunjungi warung internet (warnet). Sebagai daerah wisata maka warnet juga sudah menjamur di sekitar desa tersebut. Akibatnya banyak remaja yang menghabiskan waktunya lebih banyak di warnet daripada di rumah. Bahkan beberapa diantara mereka berani membolos karena daya tarik dari warnet. Oleh karena itu banyak permasalahan sosial pada remaja desa Gunungsari tersebut. Sebagaimana yang diceritakan oleh salah satu penggiat dari LSM Suara Perempuan desa yang berbasis di Kecamatan Bumiaji kota batu. Permasalahan tersebut diantaranya adalah adanya kenakalan remaja seperti membolos sekolah, keluar sekolah (karena lebih senang di warnet), sampai dengan beberapa kasus hamil di luar nikah pada remaja usia sekolah di desa Gunungsari tersebut. Permasalahan tersebut masih ditambah dengan tingginya tingkat pengangguran (20\%) yang ada di desa tersebut (data desa Gunungsari 2016).

Permasalahan yang terjadi di desa Gunungsari tersebut dari tahun ke tahun tidak pernah berkurang. Apalagi sejak maraknya penggunaan internet di kalangan remaja desa Gunungsari tersebut. Permasalahan tersebut selain dikarenakan rendahnya tingkat pendidikan dan pengtahuan orang tua tentang media digital juga menunjukkan bahwa literasi digital di kalangan remaja desa Gunungsari Kecamatan Bumiaji kota Batu tersebut masih sangat rendah. Hal ini sangat disayangkan, mengingat jumlah penduduk usia sekolah cukup banyak. Berdasarkan data profil desa Gunungsari Tahun 2014-2016 menunjukkan bahwa terdapat 797 pelajar/mahasiswa dan ini akan menjadi tumpuan harapan masyarakat Gunungsari untuk kehidupan yang lebih baik. Para orang tua tentu saja berharap anak-anak mereka memiliki pendidikan yang lebih baik daripada mereka.

Literasi digital merupakan ketertarikan, sikap dan kemampuan individu dalam menggunakan teknologi digital dan alat komunikasi untuk mengakses, mengelola, mengintegrasikan, menganalisis, dan mengevaluasi informasi, membangun pengetahuan baru, serta berkomunikasi dengan orang lain agar dapat berpartisipasi secara efektif dalam masyarakat (Kurniawati \& Baroroh, 2016: 54). Secara sederhana dalam pelaksanaan pengabdian masyarakat ini, literasi digital mengacu pada kemampuan atau keahlian individu memanfaatkan media digital (smartphone, komputer, internet) sebagai alat penunjang komunikasi secara benar dan optimal. Dalam arti individu tidak sekedar menggunakan media digital hanya untuk berkomunikasi tetapi juga bagaimana individu mampu memanfaatkan media digital tersebut guna meningkatkan kualitas kehidupannya. Sehingga akan minimalkan dampak negatif dari kehadiran internet pada remaja di desa Gunungsari tersebut. Permasalahan-permasalahan sosial bisa ditekan sehingga tidak ada lagi kenakalan remaja seperti bolos sekolah, berhenti sekolah sampai dengan perilaku amoral lainnya. Dengan demikian diharapkan akan meningkatkan kualitas sosial, pendidikan, budaya dan ekonomi.

Melalui literasi digital inilah remaja desa gunungsari kecamatan Bumiaji kota Batu dapat didorong untuk menjadi creativepreuneur. Hal ini sangat dimungkinkan mengingat desa Bumiaji ini dikenal memiliki potensi budidaya bunga mawar dengan luas lahan 60 hektar. Desa Gunungsari ini memiliki potensi wisata karena terletak diantara daerah perbukitan Gunung Panderman di sebelah selatan serta Gunung Arjuna di sebelah utara. Faktanya potensi tersebut belum dikesplorasi dengan optimal. Melalui literasi media digital yang optimal pada remaja di Desa Gunungsari maka akan mendorong tergalinya potensi desa Gunungsari Kecamatan Bumiaji kota Batu dengan baik.

Berdasarkan uraian situasi di atas maka yang menjadi permasalahan-permasalahan di desa Gunungsari Kecamatan Bumiaji kota Batu tersebut adalah rendahnya literasi digital. Rendahnya literasi digital tersebut dikarenakan remaja tidak pernah mendapatkan pengetahuan atau bimbingan dari orang tua mereka dalam menggunakan media digital. Orang tua mereka hanya membelikan smartphone sesuai dengan permintaan anak-anaknya tanpa pernah memahami dampak dari penggunaan gadget. Hal ini karena tingkat pendidikan orang tua yang rendah serta tingkat pengetahuan tentang media digital yang dimiliki oleh para orang tua di desa Gunungsari tersebut juga sangat minim. 
Selain rendahnya literasi digital para orang tua maka yang menjadi permasalahan kedua adalah remaja di desa Gunungsari tersebut tidak memiliki Individual competence dalam menggunakan media digital.

\section{METODE}

Pelaksanaan pengabdian pada masyarakat ini telah dilakukan dengan memberikan pelatihan pada dua kelompok masyarakat di desa Gunungsari kecamatan Bumiaji Batu. Kegiatan pengabdian masyarakat ini diawali pada tanggal 5 Mei 2018 dengan melakukan diskusi dengan Mitra dan perwakilan masyarakat setempat. Hal ini dilakukan sebagai upaya untuk mendapatkan pendekatan yang efektif dalam melakukan pelatihan yang akan dilakukan. Hasil dari kunjungan pertama tersebut disepakati bahwa Mitra akan mengundang kelompok remaja yang duduk dibangku SMP-SMA. Selain itu juga Mitra akan mengundang kelompok Ibu-Ibu yang menjadi orang tua dari para remaja tersebut.

Pada akhirnya ketika Tim Abdimas melaksanakan pelatihan Literasi Digital dilakukan pada kelompok anak usia 12-17 tahuan dengan tingkat pendidikan SMP-SMA. Meskipun pada pelaksanaannya terdapat satu anak remaja yang sudah duduk di bangku kuliah. Pelatihan yang dilakukan dengan memberikan pembekalan tentang materi literasi digital pada kategori basic.

Pelatihan kedua adalah dengan memberikan pembekalan dan pelatihan tentang Literasi Digital pada Ibu-Ibu desa Gunungsari Kecamatan Bumiaji Batu.. Pada pelatihan kedua ini dimaksudkan untuk memberikan bekal pengetahuan dan wawasan pada Ibu-Ibu tentang Internet, ciri-ciri anak yang memiliki ketergantungan pada Internet, Pendekatan Ibu pada anak-anak ketika menggunakan Internet dan strategi Ibu dalam melakukan pendampingan pada anak ketika menggunakan internet.

Metode ceramah, diskusi dan Tanya jawab guna mmeberikan pemahaman dan pengetahuan tentang penggunaan internet secara sehat pada remaja. Metode praktik dilakukan pada remaja agar mereka juga memahami konten yang baik dan benar serta ciri-ciri konten yang sifatnya hoax. Pada kelompok Ibu-ibu digunakan juga metode ceramah, diskusi dan Tanya jawab tentang internet dan cara mendampingi anak-anak dalam berselancara di dunia maya.

\section{HASIL DAN PEMBAHASAN}

\subsection{Pelatihan Literasi Digital pada Remaja tanggal 13 Juli 2018}

Kegiatan pertama yang dilakukan tim Abdimas ini dilakukan pada tanggal 13 Juli 2018 selama 7 jam yaitu dimulai pukul 09.00 - 16.00 WIB. Pelatihan tersebut dilaksanakan di rumah kegiatan "Sekolah Perempuan" yang berada di desa Gunungsari Kecamatan Bumiaji kota Batu. Kegiatan tersebut adalah melakukan pelatihan Literasi Digital pada remaja desa Gunungsari kecamatan Bumiaji Batu. Pelatihan Literasi Digital tersebut secara umum berbicara tentang bagaimana remaja dapat melakukan internet secara sehat. Kegiatan tersebut diikuti oleh 20 anak remaja yang berasal dari berbagai dusun di desa Gunungsari kecamatan Bumiaji kota batu.

Kegiatan pelatihan Literasi Digital tersebut dilakukan dalam tiga tahap yakni: (a) prakegiatan yang dilakukan dengan melakukan pretest terhadap adik-adik remaja tersebut tentang seberapa jauh pemahaman adik-adik remaja tersebut tentang internet dan untuk melihat berapa lama mereka menggunakan smartphonenya setiap hari serta apa saja yang dilakukan ketika menggunakan smartphone tersebut. (b) tahap kedua dilakukan pelatihan tentang bagaimana menggunakan internet secara sehat; (c) tahap ketiga dilakukan evaluasi guna mengukur keberhasilan dari pelatihan tersebut.

Setelah dilakuakn pretest pada remaja desa Gunungsari tersebut terlihat pengetahuan remaja terhadap aplikasi-aplikasi "kekinian" sudah mereka gunakan. Tetapi para remaja di desa Gunungsari tersebut sangat tidak peduli terhadap keamanan diri mereka di dunia maya. Selain itu juga mereka tidak mengetahui hak-hak privasi mereka ketika berselancara di dunia maya. 
Oleh karena itu memberikan pelatihan dan pemberian materi tentang melindungi dan menjaga privasi menjadi agenda pertama dalam kegiatan pengabdian masyarakat ini. Membuat keasadaran pada remaja desa Gunungsari terhadap pentingnya menjaga keselamatan diri di dunia maya adalah hal penting agar mereka bisa terhindar dari ancaman dan bahaya internet. Mengingat di Indonesia provider belum sepenuhnya memiliki system pengaman yang baik bagi penggunanya. Hal ini berbeda dengan provider yang ada di luar negeri. Adanya peraturan tentang keselamatan anak-anak ketika berada di dunia maya sehingga provider menerapkan system yang ketat pada penggunanya. Provider memiliki sistem untuk memastikan anak-anak tersebut cukup umur untuk mengakses website. Selain itu masyarakatnya memiliki kesadaran akan keselamatan anak-anak yang ditunjukkan adanya perlindungan informasi pribadi (Livimgstone, Ólafsson, \& Staksrud, 2013).

Dalam pelatihan tersebut disampaikan materi literasi melindungi dan menjaga privasi di didunia maya, memanfaatkan situs-situs pengaman, memaknai dan memahami konten digital, memilah dan memilih konten yang baik atau tidak baik untuk dirinya, menilai kredibilitas informasi, juga membuat, meneliti dan mengkomunikasikan informasi dengan alat yang tepat.

Selain itu kelompok remaja tersebut juga diberikan materi pelatihan tentang Hak-hak sebagai pengguna internet serta bagaimana menerima pertemanan dari orang yang tidak dikenal sebelumnya. Selanjutnya remaja desa Gunungsari tersebut diajarkan untuk mengakses situssitus dan VPN pengaman yang bisa melindungi privasi mereka. Terakhir materi tentang bagaimana agar remaja memiliki tanggungjawab dari setiap penyebaran informasi yang dilakukannya karena menyangkut dampaknya terhadap masyarakat. Pemberian materi tersebut diharapkan akan memberikan pengetahuan yang baik pada remaja di desa Gunungsari terutama untuk menimalkan dampak internet pada kehidupan mereka. Sebagaimana hasil banyak penelitian yang menyebutkan bahwa teknologi internet ini memberikan banyak pengaruh pada kehidupan anak-anak (Holton, 2000: 35). Penggunaan internet secara ekstensif oleh remaja telah memberikan pengaruh remaja dalam proses pengambilan keputusan (Belch, Krentler, WillysFlury, 2005: 569).

Desain pelatihan dengan metode ceramah, diskusi dan praktek bagaimana cara mengakses situs-situs pengaman privasi agar adik remaja tersebut memiliki pengetahuan dan skill tentang bagaimana menggunakan internet dengan sehat (Gambar 1).

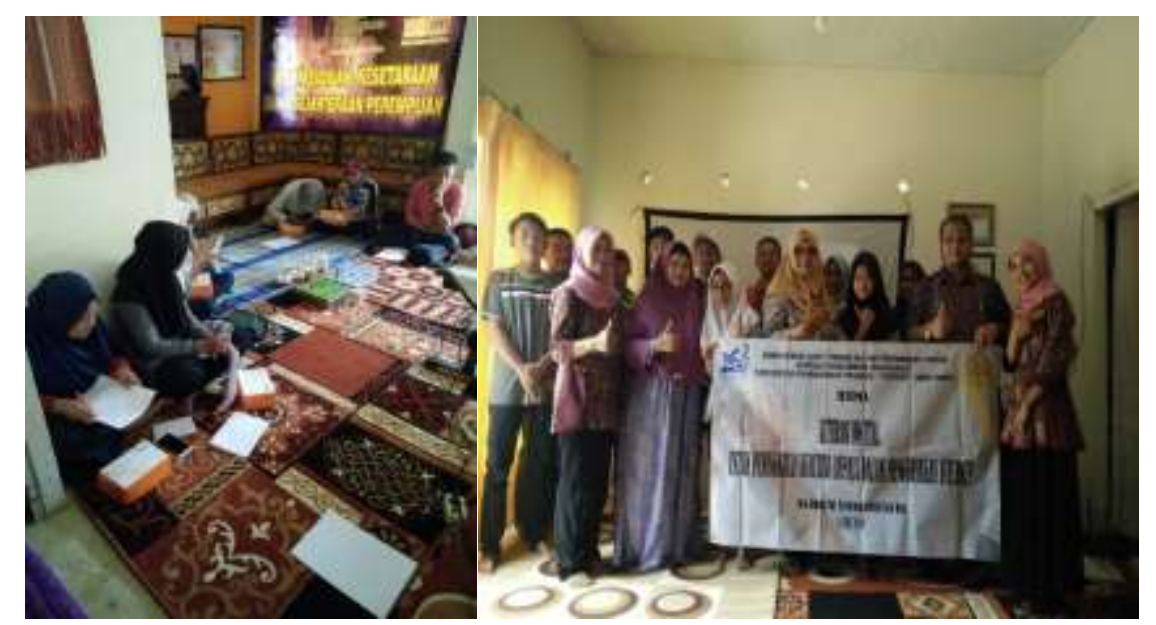

Gambar 1. Kegiatan Pelatihan Kelompok Remaja desa Gunungsari Bumiaji Batu

Hasil pelatihan Literasi Digital pada remaja desa Gunungsari mereka sudah mengubah identitas atau profil di akun media sosial yang mereka miliki. Dalam arti identitas yang tercantum pada masing-masing akun sosial media remaja desa Gunungsari sekarang tidak lagi menampilkan semua profilnya secara lengkap. Mereka hanya mencantumkan nama dan jenis kelamin. Tetapi untuk tanggal lahir, sekolah dan nama keluarga tidak lagi dicanttumkan dalam akun media sosial mereka. 
Selain itu remaja desa Gungsari saat ini sudah memahami apa saja hak-hak privasi ketika mereka berada di dunia maya dan bagaimana mereka sudah menggunakan tools yang bisa digunakan untuk melindungi mereka di dunia maya.

\subsection{Pelatihan Literasi Digital pada Kelompok Ibu-Ibu pada 15 Juli 2018}

Kegiatan pelatihan berikutnya dilakukan terhadap kelompok Ibu-Ibu pada tanggal 15 Juli 2018. Pelatihan dilakukan di rumah "Sekolah Perempuan yang berada di desa Gunungsari kecamatan Bumiaji Batu. Kegiatan pelatihan tersebut berlangsung selama 4 jam karena waktu Ibu-Ibu yang juga tidak bisa terlalu lama karena mereka selain bertani juga harus menjalankan tugas-tugas rumah tangga. Kegiatan pengabdian masyarakat ini pun baru bisa terselenggara setelah menunggu para ibu-ibu selesai dari kebun atau sawah. Pada pelatihan kedua ini dimaksudkan untuk memberikan bekal pengetahuan dan wawasan pada Ibu-Ibu tentang Internet. Materi pelatihan Literasi Digital pada kelompok Ibu-Ibu ini sangat berbeda dengan materi pada kelompok Remaja. Materi pelatihan ini meliputi Literasi tentang ciri-ciri anak yang memiliki kecanduan Internet, Pendekatan Ibu pada anak-anak ketika menggunakan Internet dan strategi Ibu dalam melakukan pendampingan pada anak ketika menggunakan internet.

Kegiatan pelatihan Literasi Digital pada kelompok Ibu-Ibu ini juga dilakukan dalam tiga tahap yakni: (a) pretest yang dilakukan dengan mengukur terhadap kelompok Ibu tersebut tentang pengetahuan dan pemahaman Ibu tentang internet dan apa yang sudah dilakukan Ibu terhadap anak ketika menggunakan internet; (b) tahap pelaksanaan dilakukan pelatihan tentang bagaimana Ibu melakukan pendampingan anak dalam menggunakan internet secara sehat; (c) tahap ketiga dilakukan evaluasi guna mengukur keberhasilan dari pelatihan tersebut.

Pada pretest yang dilakukan di awal pelatihan ini terlihat hasilnya berbeda jauh dari para remaja di desa Gunungsari tersebut. Mayoritas Ibu di desa tersebut tidak mengenal beragam aplikasi yang tersedia pada smartphone yang mereka miliki. Bahkan para ibu jarang yang menggunakan aplikasi media sosial bahkan beberapa tidak mengenal aplikasi media sosial yang banyak digunakan oleh anak-anak mereka. Bisa dipahami jika anak-anak di desa Gunungsari tidak pernah mendapatkan bimbingan atau arahan dari orang tua mereka dalam menggunakan internet. Beberapa penelitian menunjukkan bahwa remaja telah mengadopsi Internet lebih cepat daripada orang tua mereka (Hedberg dan Bedwell, 2000; 'Forty Persen,' CyberAtlas, 2000), serta remaja memiliki pemahaman yang lebih dalam tentang Internet dari pada orang-orang tua mereka (Curtis, 2000).

Desain pelatihan dengan metode ceramah, diskusi tentang internet, media sosial dan tipstips untuk mendampingi anak dalam menggunakan internet. Selain itu juga diberikan materi tentang aplikasi-aplikasi yang saat ini banyak digunakan oleh masyarakat Indonesia. Terakhir dilakukan praktek bagaimana cara mendownload aplikasi pengaman untuk anak agar anakanak tidak bisa mengakses konten-konten yang tidak baik (Gambar 2).

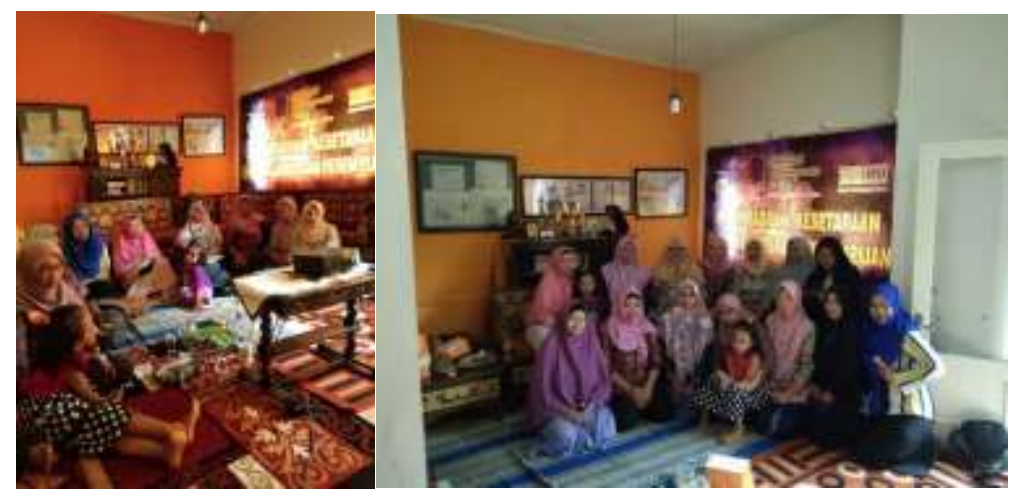

Gambar 2. Kegiatan Pelatihan Kelompok Ibu desa Gunungsari Bumiaji Batu 
Evaluasi keberhasilan dari pelatihan tersebut dilakukan dengan melakukan diskusi dan simulasi pada Ibu-Ibu tentang bagaimana Ibu menghadapi anak-anak ketika ada kencenderungan memiliki ketergantungan tinggi terhadap internet. Selain itu dengan menguji bagaiamana Ibu mampu menggunakan salah satu aplikasi pengaman untuk anak.

Hasil pelatihan Literasi Digital pada kelompok Ibu-Ibu ini adalah meningkatnya pengetahuan Ibu tentang dunia internet serta bagaimana cara Ibu dapat memberikan fasilitas internet pada anak-anak. Selain itu Ibu-Ibu juga sudah mengunduh aplikasi-aplikasi yang aman untuk melindungi anak-anak mereka terutama usia balita sampai dengan usia Sekolah Dasar dari situs-situs yang tidak pantas diakses anak-anak. Selain itu Ibu-Ibu juga sudah memahami ciri-ciri dari anak yang mengalami ketergantungan terhadap internet, sehingga diharapkan Ibu dapat melindungi anak-anaknya dari ketergantungan anak terhadap penggunaan internet yang tinggi sehingga tidak menimbulkan kecanduan pada perilaku anak.

\section{KESIMPULAN}

Kegiatan pengabdian masyarakat yang dilakukan di Desa Gunungsari kecamatan Bumiaji kota Batu telah dilaksanakan. Hasil kegiatan dari pengabdian masyarakat ini telah memeberikan dampak yang cukup baik pada diri remaja di desa tersebut. Mereka sudah mampu melindungi dri sendiri dengan tidak mengunggah semua informasi pribadinya di akun-akun media sosialnya. Mereka juga mengenali apa saja hak-hak privasi ketika di dunia maya. Selain itu para Ibu sudah mengenal ciri-ciri kecanduan gadget pada anak-anak dan sudah mampu melindungi anak-anak mereka dari situs-situs yang tidak layak bagi anak-anak.

\section{UCAPAN TERIMA KASIH}

Terkait dengan hasil pengabdian masyarakat ini kami menyampaikan terima kasih kepada LPPM UPNV Jatim yang telah memberikan dukungan dana dan memberikan kesempatan kepada Tim dalam melaksanakan kegaitan pengabdian masyarakat tentang pengembangan dan pendampingan Literasi Digital pada masyarakat desa Gunungsari, kecamatan Bumiaji kota Batu.

\section{DAFTAR PUSTAKA}

Belch, A Michael, Krentler, A. Kathreen, Willis-Flury, A. Laura. 2005. Teen internet mavens: influence in family decision making. Journal of Business Research. Vol. 58 p: 569-575

Candrasari, Yuli. 2016. Social media and Social Change: Self Identity Construction and Self Presentation in Cybersociety. Proceeding Internasional Seminar Research Month: Innovation, Development, and Utilition of Research and Community Service. LPPM UPN Veteran Jatim 2016. ISBN : 978-602-72352-3-6 Halaman 673 - 682

Carver, L. Doris. 2000. Representation of Women in The Information Technology Workforce. Paper.

Claretta, Dyva., Arianto,D. Irwan. (2018) Pendampingan Ibu pada Anak dala Menggunakan Internet. Jurnal Ilmu Komunikasi UPNV Jogjakarta Vol. 16 No. 2 Tahun 2018. http://jurnal.upnyk.ac.id/index.php/komunikasi/article/view/2689

Curtis J. Wired youth. 2000. Campaign 2000; (October 20):33.

Forty percent of America's kids online. CyberAtlas 2000; June 8, 3-16-01. Available at: http://cyberatlas.internet.com/big_picture/demographics/ article/0,5901_390941,00.html

Hedberg A, Bedwell R. 2000. Tapping into generation tech. Mark Week; 23(December 21):24 5.

Holton L. The surfer in the family. Am Demogr 2000;22(April):34 - 6

Kurniawari, Juliana dan Baroroh, Siti. 2016. Literasi media Digital Mahasiswa Universitas Muhammadiyah Bengkulu. Jurnal Komunikator Vol. 8 No. 2 Tahun 2016. http://journal.umy.ac.id/index.php/ikm/article/view/2069/2586 
Lenhart A, Rainie L, Lewis 0. 2001. Teenage life online: the rise of the instantmessage generation and the Internet's impact on friendships and family relationships. Washington, DC: Pew Internet and American Life Project.

Livingstone, S., Ólafsson, K., \& Staksrud, E. (2013). Risky social networking practices among "underage" users: lessons for evidence-based policy. Journal of Computer-Mediated Communication , 18 (3), 303-320

Lutviah. 2011. Pengukuran Tingkat Literasi Media Berbasis Individual Competence Framework: Studi kasus Mahasiswa Universitas Paramadina. Skripsi. Tidak diterbitkan. Jakarta: Direktorat Quality/Assurance, Research and knowledge Management, Universitas Paramadina.

Sasmito, Wiro Ginanjar, Wijayanto, Sena., Zulfiqar, M, La Ode. 2020. Studi Pengenalan Internet of Things Bagi Guru dan Siswa SMK Bina Nusa Slawi Sebagai Wawasan Salah Satu Ciri Revolusi Industri 4.0. Jurnal Dinamisia: Jurnal Pengabdian kepada Masyarakat. Vol. 4 No. 1 Maret 2020. 